\title{
Effects of the Heterogeneity of the Landscape and the Abundance of Wasmannia auropunctata on Ground Ant Assemblages in a Colombian Tropical Dry Forest
}

\author{
Rafael Achury, ${ }^{1}$ Patricia Chacón de Ulloa, ${ }^{1}$ and Ángela Arcila ${ }^{2}$ \\ ${ }^{1}$ Grupo de Investigación en Biología, Ecología y Manejo de Hormigas, Departamento de Biología, Universidad del Valle, \\ Calle 13 No. 100-00, AA 25360 Cali, Colombia \\ ${ }^{2}$ Corporación Colombiana de Investigación Agropecuaria (Corpoica), E.E Caribia, Km 6 vía Sevilla, Zona Bananera, \\ Magdalena, Colombia
}

Correspondence should be addressed to Rafael Achury, rafaelachury@gmail.com

Received 2 May 2011; Accepted 8 August 2011

Academic Editor: Jonathan D. Majer

Copyright () 2012 Rafael Achury et al. This is an open access article distributed under the Creative Commons Attribution License, which permits unrestricted use, distribution, and reproduction in any medium, provided the original work is properly cited.

\begin{abstract}
To evaluate the response of the ant assemblages to different management practices in the tropical dry forests of southwestern Colombia, 10 sites that conserve forest fragments surrounded by pastures and sugarcane crops were sampled. Tuna-fish baits placed on the ground in the three habitats captured 100 ant species (41 genera). The greatest number of species was found in the forests in contrast with a significant loss of richness and diversity in the productive habitats, the pastures being richer than the cane fields. Species richness was negatively correlated with the abundance of the little fire ant Wasmannia auropunctata. Ant species composition was related to soil temperature and percent ground cover, as well as being partially determined by location and the abundance of $W$. auropunctata. The forests had a significantly different species composition from the other two habitats, but there were no consistent differences between the pastures and the cane fields.
\end{abstract}

\section{Introduction}

The commonest consequence of converting tropical forests on a large scale is a mosaic of fragments of relictual vegetation surrounded by productive habitats such as pastures for cattle, sugarcane crops, and oil palm plantations [1, 2]. Modifications of the natural habitat generally result in loss of species and changes in the composition and diversity of different animal groups [3-6] including insects [7-9]. To understand the effects of transforming the natural habitat, it is important to examine how the richness and composition of species change in areas that contain differentsized fragments as part of one large disturbed matrix [10].

The tropical dry forest is one of the most transformed and threatened ecosystems in the world $[11,12]$. Of the $519,597 \mathrm{~km}^{2}$ of remnants of this forest distributed throughout the Americas, half the area (51\%) is found in South America [13], where conversion to agriculture represents a substantial risk to the highly fragmented patches of dry forest
[14]. Of the $30,713 \mathrm{~km}^{2}$ of dry forest existing in Colombia today, $1977 \mathrm{~km}^{2}$ [13], are found in the geographic valley of the Cauca River, spread out in more than 1600 fragments with an average size of 6 ha [15]. This situation is the consequence of the expansion of the sugarcane monocrop and pastures [16].

Given the urgency of determining the biodiversity in the relictual forests of the Cauca River Valley, studies have been conducted on ants and Staphylinidae (Coleoptera) [17], highlighting the need for obtaining information about the structure and dynamics of the biotic communities in these forest remnants and their adjacent matrixes.

Ants have a large number of attributes, offering many possibilities for monitoring, inventorying, and basic ecology $[18,19]$. In addition to their high diversity and dominance in terms of biomass and numbers, particularly in tropical forests $[20,21]$, the ground-foraging ant assemblage is especially sensitive to impacts due to transformation of the habitat [22], because of this, they have been widely 
used as indicator species [23]. Many studies report that such disturbances promote changes in the structure and composition of the ant assemblages [24, 25], loss of species richness [26], reduced density of nests within the fragments $[27,28]$, and a high number of tramp species in fragments as compared with continuous forests [29].

In the dry forests of southwestern Colombia, where some 200 ant species have been recorded [17], the forest fragments conserve greater species richness than their adjacent matrixes [30]. Moreover, the richest forests have a greater number of rare species [31], and the richness and relative frequency of some groups (e.g., legionary or army ants) are correlated positively with the area [32]. Although the actual composition of ant species varies significantly among sampling sites [33], the little fire ant (Wasmannia auropunctata R.) is numerically dominant; thus, it has been proposed as an indicator of low diversity in the dry forest [34].

This study compared the richness and composition of the ground ant community at 10 sites in the three different habitats: forest fragments, pastures for cattle-raising, and sugarcane crops. The objective was to determine the effect of the different sites and habitats on the richness and composition of ant species, taking into account a gradient of disturbance and environmental and biotic variables. In addition, the study aimed to determine whether the changes in species richness and composition were conditioned by the presence of dominant ants. Finally, based on the results, a broader view for conserving forest fragments and using sustainable management practices for the associated habitats can now be provided.

\section{Materials and Methods}

2.1. Study Area. Located in southwestern Colombia, the area corresponds to the inter-Andean floodplain formed by the upper watershed of the Cauca River, with an area $230 \mathrm{~km}$ long by $10-20 \mathrm{~km}$ wide and at an altitude of $900-1100 \mathrm{~m}$. The climate is typical of a tropical dry forest, with an average annual temperature of $24^{\circ} \mathrm{C}$ and $1000-2000 \mathrm{~mm}$ of rainfall, distributed in two periods (April-May and OctoberNovember), during which $70 \%$ of the total annual rainfall occurs [35].

Ten sites were selected, distributed from South to North, covering three states in southwestern Colombia (Table 1). Each site comprises a forest fragment whose arboreal vegetation reaches a canopy of $30 \mathrm{~m}$, with prominent species of wild cashew (Anacardium excelsum), Xylopia ligustrifolia, Laetia americana, cow or wild fig (Ficus glabrata), Cecropia sp., and kapok (Ceiba petandra) [36], frequently mixed with clumps of Guadua angustifolia (Tribe Bambuseae). The forest fragments differ in shape, area, and type of matrix [37], in which pastures for cattle raising (36\% of the area) and intensive sugarcane production (52\%) predominate [15].

2.2. Sampling of Ants. Sampling was performed during the rainy season, from October to December, 2005 and February to May, 2006. Three habitats were identified at each site: forest, sugarcane fields, and pastures. All the pastures and cane fields surveyed were adjacent to the forest. Linear transects were marked off at random in each habitat, and 40 sampling stations were placed every $20 \mathrm{~m}$ to guarantee independence of the samples based on the ants' foraging distances [38]. All transects were placed parallel to the forest edges at a minimum distance of $50 \mathrm{~m}$. At each sampling station, coordinates were taken (GPS Garmín 12XL); and four variables were measured: soil moisture, soil $\mathrm{pH}$ (Kelway meter), soil temperature (Weksler thermometer), and canopy cover (spherical concave densitometer, Forestry Suppliers, Inc.).

The ants were collected using tuna-fish baits, one per sampling station. This method is useful for estimating the composition and richness of the ant fauna that forage actively on the ground [39] and has been widely used in dry forests $[30,31,34]$. The baits, previously evaluated by Achury et al. [33], consisted of a piece $(4 \times 4 \mathrm{~cm})$ of white bond paper, on which was placed an average of $9 \mathrm{~g}( \pm 1.7)$ of tuna fish conserved in oil. They were then put on the ground and left there for 3 hours. The ants that were found directly on the tuna fish were collected, and the rest of the bait, including part of the soil beneath, was also picked. This was done because on underside of the paper, there were often very small or less aggressive ant species.

The samples were cleaned in the laboratory and conserved in ethanol at $80 \%$. Their identification was done to the genus level according to Palacio and Fernández [40] and Bolton [41]. At the species level, Longino's key [42] was used, as well as to comparing ants with specimens from the Museum of Entomology at the Universidad del Valle (MEUV) and the Museum of Zoology at the Universidade de São Paulo (MZUSP). The reference collection was deposited in the MEUV.

2.3. Data Analyses. For each sample (1 tuna-fish bait), the number of morphospecies of ants that were attracted to the bait and their respective abundances were counted. A descriptive analysis was done of the percent occupation of the baits by the different subfamilies, genera, and certain species.

To determine the differences with respect to ant richness and composition, two scales were analyzed: sites (total 10) and habitats (total 3, represented by forests, cane fields, and pastures). Correlations were sought between species richness per site versus three variables: latitude, total number of captures, and abundance of the commonest species $(W$. auropunctata). A correlation was also run between latitude and abundance of $W$. auropunctata. The richness per habitat was compared using rarefaction curves based on samples [43, 44], using the Estimates $S$ program v. 8.2 [45]. Data on species density were used because they provide a better indicator of the differences in structure within the habitats [24].

The three habitats were compared with respect to four variables: abundance of ants per bait (natural logarithm), species richness per bait, the Shannon diversity index, and the numeric dominance index (ratio between number of workers of the most abundant species and total abundance of all species in the habitat). A one-way analysis of variance (the Kruskal-Wallis test) was applied, and multiple comparisons 
TABle 1: Description of the location and characteristics of the sites within fragments of tropical dry forest in the upper watershed of the Cauca River; sites ordered geographically from North to South.

\begin{tabular}{|c|c|c|c|c|c|}
\hline Site & Adjacent matrix & Municipality and state & Coordinates & Altitude (masl) & Area (ha) \\
\hline Miralindo I & Pastures & La Virginia, Risaralda & $\begin{array}{l}4^{\circ} 54^{\prime} 19.89^{\prime \prime} \mathrm{N} \\
75^{\circ} 51^{\prime} 30.5^{\prime \prime} \mathrm{W}\end{array}$ & 900 & 6.7 \\
\hline Aguas Claras & $\begin{array}{l}\text { Pastures and } \\
\text { sugarcane }\end{array}$ & Pereira, Risaralda & $\begin{array}{c}4^{\circ} 53^{\prime} 23.1^{\prime \prime} \mathrm{N} \\
75^{\circ} 55^{\prime} 56.6^{\prime \prime} \mathrm{W}\end{array}$ & 940 & 13.0 \\
\hline Alejandría & Pastures & La Virginia, Risaralda & $\begin{array}{l}4^{\circ} 49^{\prime} 58.6^{\prime \prime} \mathrm{N} \\
75^{\circ} 53^{\prime} 2.4^{\prime \prime} \mathrm{W}\end{array}$ & $900-940$ & 15.3 \\
\hline Las Pilas & Pastures & Zarzal, Valle & $\begin{array}{c}4^{\circ} 26^{\prime} 25.7^{\prime \prime} \mathrm{N} \\
75^{\circ} 59^{\prime} 23.1^{\prime \prime} \mathrm{W}\end{array}$ & 1000 & 12.4 \\
\hline El Medio & Sugarcane & Zarzal, Valle & $\begin{array}{l}4^{\circ} 20^{\prime} 13.8^{\prime \prime} \mathrm{N} \\
76^{\circ} 5^{\prime} 0.1^{\prime \prime} \mathrm{W}\end{array}$ & 950 & 13.1 \\
\hline Las Chatas & $\begin{array}{l}\text { Pastures and } \\
\text { sugarcane }\end{array}$ & Buga, Valle & $\begin{array}{c}3^{\circ} 51^{\prime} 20.8^{\prime \prime} \mathrm{N} \\
76^{\circ} 20^{\prime} 5.35^{\prime \prime} \mathrm{W}\end{array}$ & 950 & 10.8 \\
\hline El Vínculo & Pastures & Buga, Valle & $\begin{array}{c}3^{\circ} 50^{\prime} 2.38^{\prime \prime} \mathrm{N} \\
76^{\circ} 17^{\prime} 19.7^{\prime \prime} \mathrm{W}\end{array}$ & $980-1150$ & 15 \\
\hline El Hatico & $\begin{array}{l}\text { Pastures and } \\
\text { sugarcane }\end{array}$ & El Cerrito, Valle & $\begin{array}{c}3^{\circ} 38^{\prime} 34.48^{\prime \prime} \mathrm{N} \\
76^{\circ} 19^{\prime} 40.52^{\prime \prime} \mathrm{W}\end{array}$ & 980 & 12.6 \\
\hline Colindres & $\begin{array}{l}\text { Pastures and } \\
\text { sugarcane }\end{array}$ & Jamundí, Valle & $\begin{array}{l}3^{\circ} 16^{\prime} 25.8^{\prime \prime} \mathrm{N} \\
76^{\circ} 29^{\prime} 31^{\prime \prime} \mathrm{W}\end{array}$ & 975 & 10.0 \\
\hline San Julián & $\begin{array}{l}\text { Pastures and } \\
\text { sugarcane }\end{array}$ & $\begin{array}{c}\text { Santander de Quilichao, } \\
\text { Cauca }\end{array}$ & $\begin{array}{c}3^{\circ} 06^{\prime} 38.8^{\prime \prime} \mathrm{N} \\
76^{\circ} 31^{\prime} 41.2^{\prime \prime} \mathrm{W}\end{array}$ & 950 & 3.5 \\
\hline
\end{tabular}

were made using the Tukey test and Bonferroni correction [46].

Species composition was described using the data on frequency of capture for all the species, and the similarity among the sampled sites was determined by means of hierarchical cluster analysis [47]. Then, the PC-ORD program v. 4 [48] was used to compare the groups formed, using the nonparametric multivariate technique MRPP (Multiresponse permutation procedure), which tests the null hypothesis of there being no difference between two or more groups of entities, based on previously defined groups $[47,49]$. This technique was also used to compare the ant assemblages among habitats.

To examine whether the environmental variables (soil moisture, $\mathrm{pH}$, temperature, and percent ground cover) and biotic variables (species richness and abundance of $W$. auropunctata) are related to the ant assemblage structure (frequency of capture per habitat), a canonical correspondence analysis (CCA) [48] was performed, followed by the Monte Carlo significance test (999 permutations). These analyses were done with the PC-ORD program v. 4.

\section{Results}

3.1. General Data on Ants Collected. Of the 1062 baits placed, 93.03\% scored positive for ants, with an average per site of $92.83 \%( \pm 6.41)$ (Table 2). A total of 194,347 ants were attracted to the tuna-fish baits, classified into 100 species, 41 genera and 8 subfamilies (see the appendix). Myrmicinae was the subfamily with the most genera and species (24 and 66, resp.), followed by Dolichoderinae (5 genera, 7 species), Formicinae $(4,16)$, Ponerinae $(2,4)$, Ecitoninae
$(2,2)$ Ectatomminae $(2,2)$, Pseudomyrmecinae $(1,2)$, and Heteroponerinae $(1,1)$. The richest genera were Pheidole (19 species), Crematogaster (9), Solenopsis (8), and Camponotus (4). The dominant species in the study were $W$. auropunctata $(130,757$ workers) and Solenopsis geminata $(29,565)$, together representing $82.5 \%$ of the captures.

3.2. Richness and Abundance. The average number of ant species per site was 30.4 (minimum 17, maximum 46), with higher values toward the North of the study area (Table 2). Except for two sites (Colindres and San Julián), where the pastures or cane fields, respectively, had the greatest species richness, more species were recorded in the forest habitat (Figure 1). The rarefaction curves showed that the forests had the greatest richness compared with the pastures and cane fields $\left(F_{2,12}=789.34 ; P<0.001\right)$, which had the lowest number of species (Figure 2).

A highly significant positive correlation was found between richness and latitude $(r=0.8453 ; \mathrm{df}=8 ; P=0.002)$. In contrast, a highly significant negative correlation was found between abundance of $W$. auropunctata and latitude $(r=-0.9581 ; \mathrm{df}=7 ; P<0.001)$. Species richness per site varied inversely with the total captures of $W$. auropunctata $(r=-0.8062 ; \mathrm{df}=7 ; P=0.008)$ and its respective abundance $(r=-0.8569 ; \mathrm{df}=7 ; P=0.003)$.

Significant differences were found among the habitats for the variables ant abundance per bait $\left(F_{2,985}=12.31\right.$; $P<0.0001)$ and species richness per bait $(H=25.86$; $\mathrm{df}=2, n=988 ; P<0.001)$, as well as for the Shannon diversity index $\left(F_{2,22}=21.13 ; P<0.001\right)$. Abundance was greater in the cane fields and the forest than in the pastures (Tukey: $P<0.001$ ) (Figure 3(a)), while richness was greater 


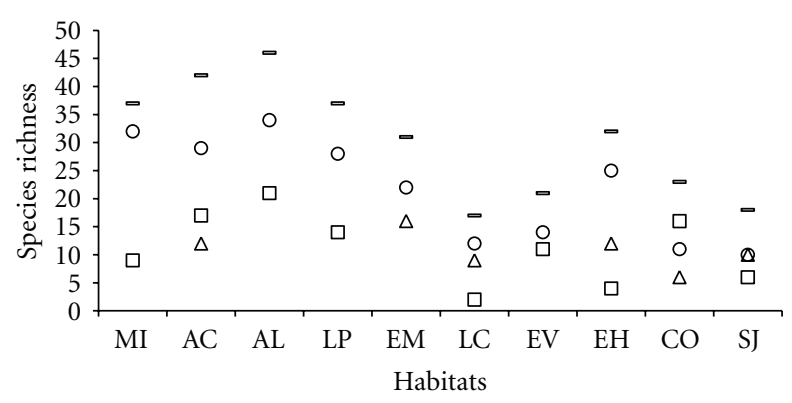

$$
\begin{array}{ll}
\Delta \text { Cane fields } & \circ \text { Forest } \\
\square \text { Pastures } & - \text { Total }
\end{array}
$$

FIgURE 1: Richness of ant species broken down by habitat at 10 sites ordered geographically from North to South. MI (Miralindo), AC (Aguas Claras), AL (Alejandría), LP (Las Pilas), EM (El Medio), LC (Las Chatas), EV (El Vínculo), EH (El Hatico), CO (Colindres), and SJ (San Julián).

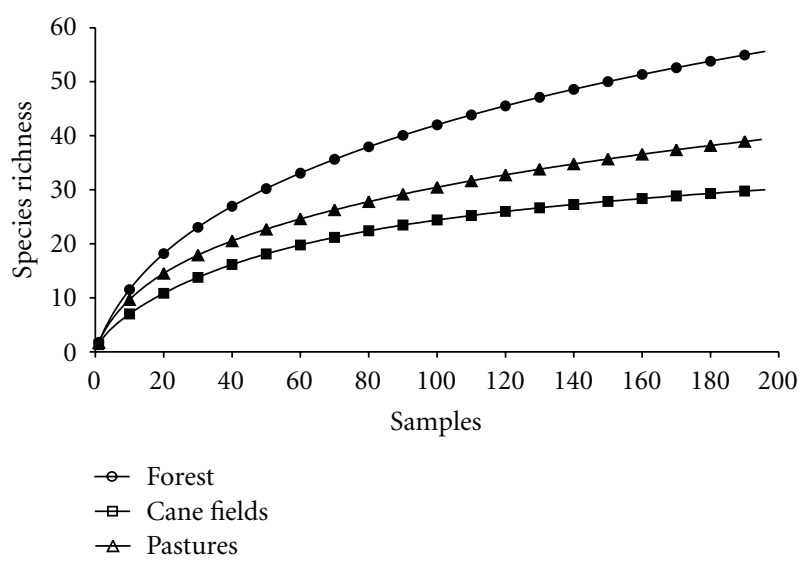

Figure 2: Rarefaction curves, based on the Coleman method, for species of ants captured at tuna-fish baits in three habitats within the tropical dry forest region. For purposes of clarity, the confidence intervals (95\%) and the SD are omitted in the figure.

in the pastures and forest (Bonferroni correction: $P<0.001$ ) (Figure 3(b)). The diversity index was significantly greater in the forest (Tukey: $P<0.001$ ) (Figure 3(c)). No significant differences were found for the dominance index $\left(F_{2,19}=\right.$ $0.13 ; P=0.87)$ given that in the three habitats it was higher than $60 \%$ (Figure 3(d)). Wasmannia auropunctata ant was dominant in the forest and cane fields, whereas in the pastures its index was low $(36 \%)$, the dominant species being S. geminata.

3.3. Species Composition. Based on the dendrogram, four groups were differentiated with a level of retention of over $50 \%$ (Figure 4). There were significant differences in ant composition among sites (MRPP: $A=0.129 ; T=-4.408$; $P=0.0002$ ), which were determined by geographic location and the abundance of $W$. auropunctata. The first group was formed by the four sites in the North, which also had the lowest abundance of W. auropunctata (Aguas Claras,
TABLE 2: Effectiveness of tuna-fish baits and total richness of ant genera and species in the study area.

\begin{tabular}{lccc}
\hline Site & Bait attraction (\%) & No. of genera & $\begin{array}{c}\text { No. of } \\
\text { species }\end{array}$ \\
\hline North & & & \\
$\quad$ Miralindo & 95.6 & 23 & 37 \\
Aguas Claras & 96.8 & 21 & 42 \\
Alejandría & 87.2 & 22 & 46 \\
Las Pilas & 96.7 & 18 & 37 \\
\hline Midzone & & & \\
El Medio & 97.5 & 15 & 31 \\
Las Chatas & 86.7 & 13 & 17 \\
El Vínculo & 78.9 & 15 & 21 \\
Hatico & 95.0 & 21 & 32 \\
\hline South & & & \\
Colindres & 95.0 & 17 & 23 \\
San Julián & 98.7 & 12 & 18 \\
\hline Average \pm SD & $92.8 \pm 6.41$ & $17.7 \pm 3.92$ & $30.4 \pm 10.24$ \\
\hline
\end{tabular}

Alejandría, Miralindo, and Las Pilas). In Las Chatas, which was separate from the other sites, no $W$. auropunctata ants were captured. The third group covered the midzone of the geographic valley of the Cauca River (El Hatico, El Vínculo, and El Medio). Lastly, the fourth group was formed by the two sites in the South (Colindres and San Julián), where the greatest abundance of $W$. auropunctata was found.

The CCA showed that the habitats formed separate groups that varied with respect to the composition of ants (Figure 5), which was significant globally (MRPP: $A=0.116$; $T=-5.847 ; P=0.0001)$. However, the differences were between the forest and pastures (MRPP: $A=0.124 ; T=$ $-6.263 ; P=0.0003$ ) and the forest and cane fields (MRPP: $A=0.067 ; T=-3.475 ; P=0.007)$; but not between the pastures and cane fields (MRPP: $A=0.052 ; T=-1.757 ; P=$ 0.063 ). Moreover, the canonic regression (Table 3 ) shows that that there is a strong relationship between the community structure and the variables soil temperature, percent ground cover, abundance of $W$. auropunctata, and richness of ant species, of which the first three were strongly associated with the second axis, while the last one was associated with the first axis. The variables $\mathrm{pH}$ and soil moisture had weak relationships with the composition of ants. The proper values (eigenvalues) for the first two axes explained the highest percent of cumulative variance $(21.7 \%)$ and were significant (Table 3).

\section{Discussion}

Sampling methods in this study did not include collecting litter, so it would be expected that species richness would not be as high; however, the 100 ant species collected with the tuna-fish baits in the 10 dry forest fragments represent $50 \%$ of the species recorded in the study area [17]. Myrmicinae was the most diverse subfamily, with five times more genera 


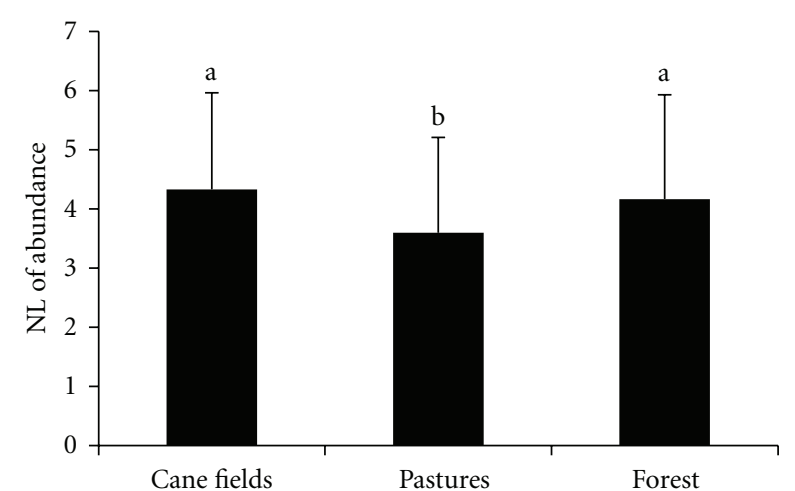

(a)

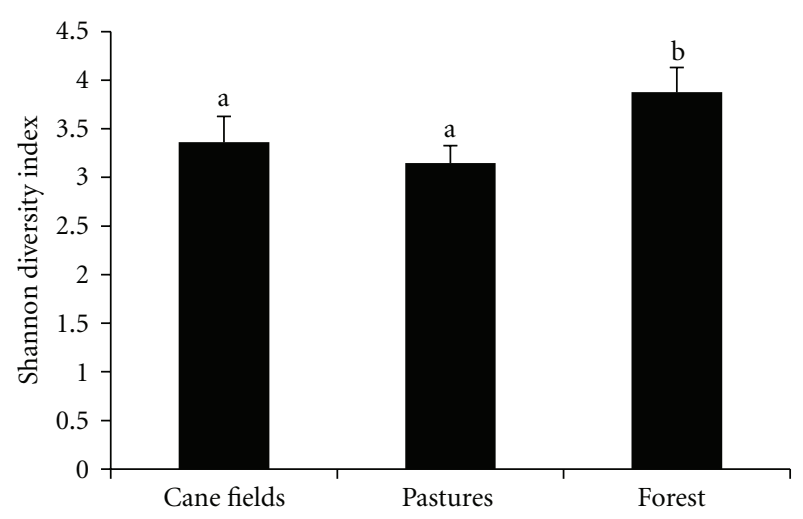

(c)

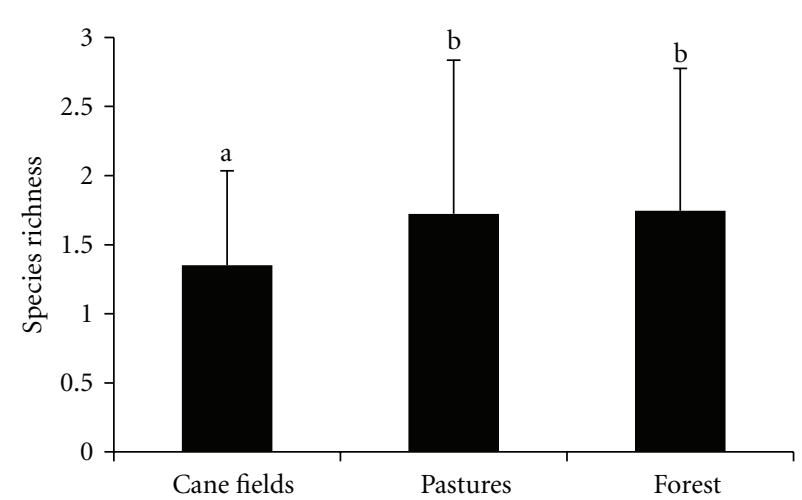

(b)

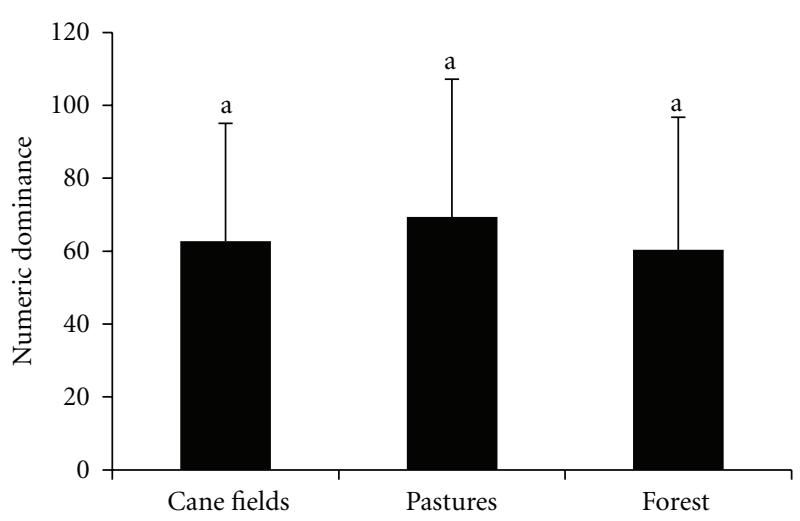

(d)

FIGURE 3: Average values and SD for (a) natural logarithm of the abundance of ants per bait; (b) species richness per bait; (c) shannon diversity index, and (d) numeric dominance of the most abundant species in each habitat. Bars with different letters are statistically different.

TABle 3: Summary of the CCA statistics for each axis and the Monte Carlo significance test for the proper values (eigenvalues) based on 999 permutations.

\begin{tabular}{lccc}
\hline & Axis 1 & Axis 2 & Axis 3 \\
\hline Eigenvalue & 0.538 & 0.319 & 0.006 \\
Monte Carlo probability test & 0.001 & 21.7 & 0.015 \\
\% cumulative variance in species data & 13.7 & & 27.6 \\
\hline Variables of the canonic multiple regression & & 0.104 & -0.172 \\
Soil moisture & -0.038 & -0.170 & -0.141 \\
pH & 0.080 & 0.314 & -0.086 \\
Soil temperature & -0.141 & -0.480 & -0.784 \\
\% ground cover & 0.304 & -0.268 & 0.984 \\
Abundance of $W$. auropunctata & 0.170 & 0.787 & 0.482 \\
Species richness & 0.713 & & \\
\hline
\end{tabular}

and four times more species than the other subfamilies. This preeminence can be explained by the great adaptive radiation, range of foraging behaviors, nesting habits, and colony structure of this subfamily [20], which includes the genus Pheidole, which had the greatest richness (19 species) and which is represented by 651 species in the New World [50].

In the study area, agricultural intensification has occurred from the edges of the Cauca River in the flatlands toward the foothills [16]. Species' richness increased toward the North of the study area (Figure 1), where the sampled sites are found close to the foothills of the central and western Andean mountain ranges; by contrast, the sites in the South are found in the flatlands closer to the edge of the Cauca River. Arcila-Cardona et al. [37] showed that the sites located to the North are more interconnected than the midzone and South of the geographic valley and are surrounded by gallery forests and patches of Guadua angustifolia, which increases 


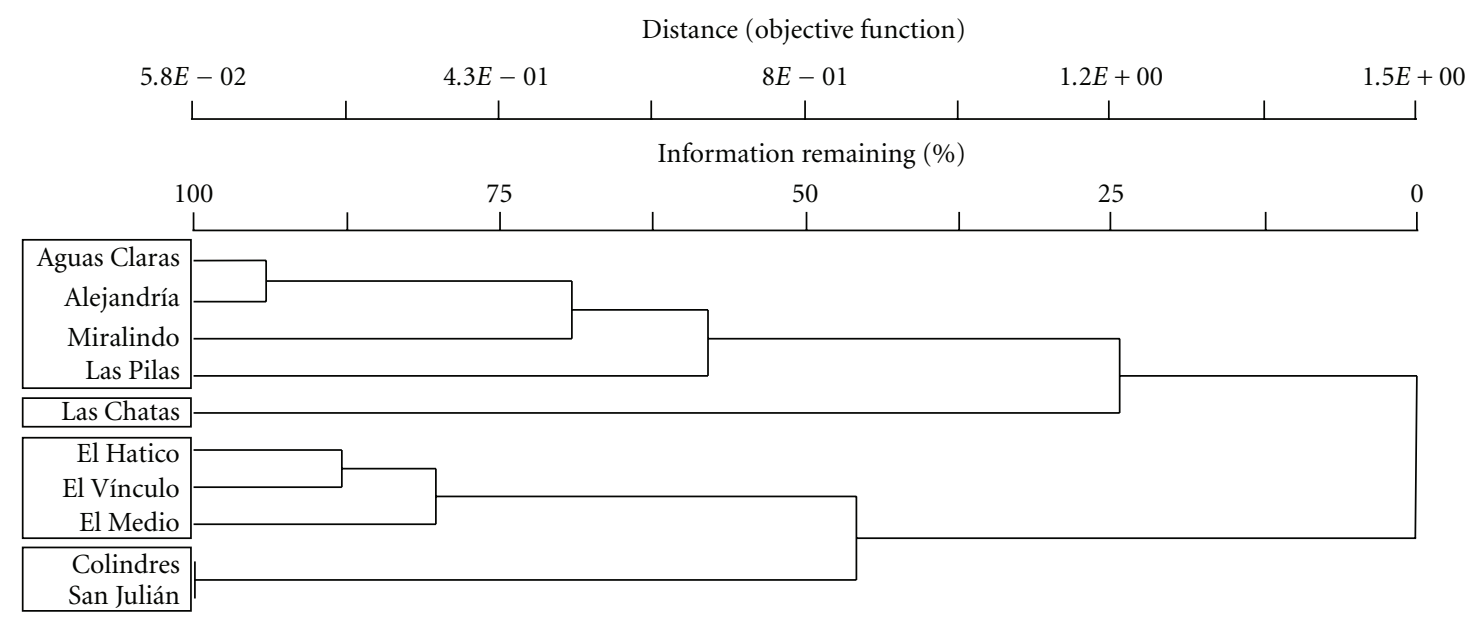

FIGURE 4: Clustering of the ant assemblages at the 10 sampled sites, based on the Sorensen (Bray-Curtis) index of dissimilarity and the Beta-flexible clustering method $(b=-0.25)$. Percent concatenation: $10 \%$.

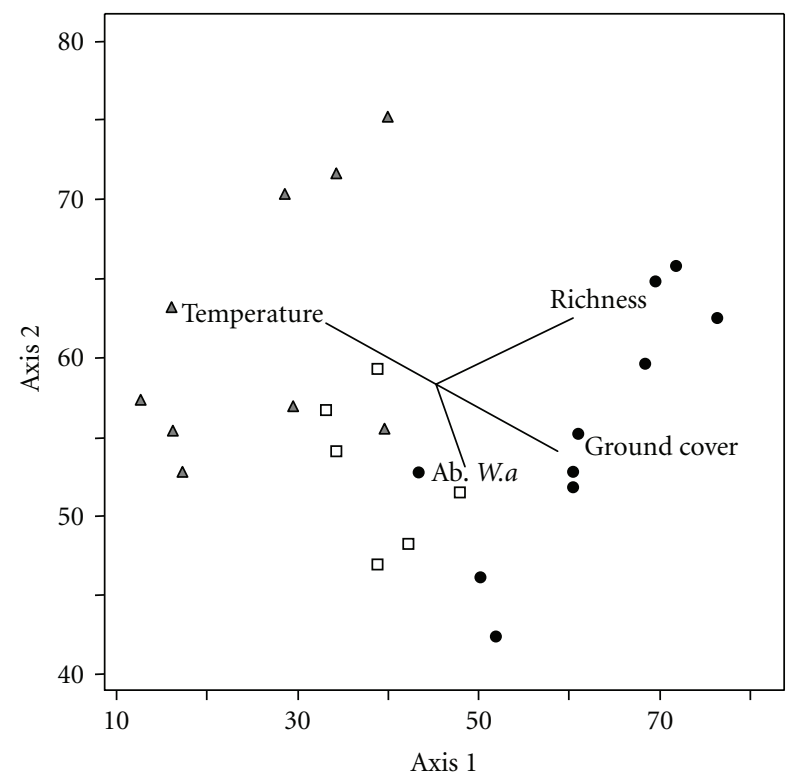

Figure 5: Canonical correspondence analysis (CCA) of the composition of ants in three habitats ( $\bullet$ : Forest; $\mathbf{\Delta}$ : Pastures; $\square$ : Cane fields). The lines show the direction and strength of the relationship of the environmental and biotic variables with respect to the structure of the ant assemblage per habitat.

the heterogeneity of the landscape and favors the movement of ant species among sites. This result is related to what Cook et al. found [51], where small or isolated fragments maintain high species richness due to the availability of colonizers from adjacent heterogeneous matrixes. Another phenomenon that can affect the species richness of ground ants is the periodic flooding that affects the sites in the South with greater frequency [16]. This stochastic event could alter the availability and quality of the habitat dramatically [22], resulting in a reduction in the richness of ants [52] when they are forced to move their nesting sites regularly [53].
The inverse correlation between species richness and the abundance of $W$. auropunctata reinforces the idea that the little fire ant can be used as an indicator of low diversity in ant assemblages [34]. This species is 10 times more abundant toward the South of the region sampled, where the process of fragmentation has been more aggressive [16]. Under these circumstances, $W$. auropunctata has largely displaced the ant fauna in some areas of the tropical forest in southwestern Colombia, accounting for up to $84 \%$ of the total captures. The increase in invasive or aggressive species is one of the effects of fragmentation that has been reported with greatest frequency $[28,29,54-56]$ and has had negative effects on the native fauna, decreasing the utilization of resources for other species of ants and other arthropods, thereby affecting plants and associated arthropods, either directly or indirectly [22]. Although $W$. auropunctata is a very common native species of neotropical forests that does not usually dominate entire assemblage [57-59], in disturbed areas such as agricultural and forestry systems, as well as in regions outside its native range, the little fire ant commonly has enormous populations $[60,61]$ and is capable of exterminating ant populations over large areas [20]. That result is in agreement with those found in this study.

In agreement with the rarefaction curve (Figure 2), there are significant differences in the number of species per habitat, which shows that management has an important effect on the ant fauna in these tropical dry forests. Species richness is greatest in the forests and lowest in the cane fields. The comparison among habitats indicates a significant loss of species between the forest and productive habitats, given that the forests have 51 species that were not recorded in either the cane fields (only 3 exclusive species) or the pastures (8 species). This pattern of species richness is common in tropical zones [24, 27, 62], where the richness declines along a gradient of succession or disturbance. Majer et al. [63] showed that the permanent transformation of forests to crops dramatically reduces species richness. Perfecto et al. [64] reviewed 22 studies, of which 18 reported that ant diversity decreased with the intensification of agriculture. In 
TABLE 4: List of ant species sampled and their abundance at baits along a tropical dry forest region of southwestern Colombia.

\begin{tabular}{|c|c|c|c|c|c|}
\hline Species & Forest & Cane fields & Pastures & $\begin{array}{c}\text { Total } \\
\text { abundance }\end{array}$ & $\begin{array}{c}\% \text { occupation } \\
\text { of baits }\end{array}$ \\
\hline \multicolumn{6}{|l|}{ Dolichoderinae } \\
\hline Azteca instabilis* & 1324 & 26 & 0 & 1350 & 5.36 \\
\hline Azteca sp. 1 & 29 & 0 & 0 & 29 & 0.10 \\
\hline Dolichoderus bispinosus* & 1279 & 0 & 0 & 1279 & 3.74 \\
\hline Dorymyrmex brunneus & 0 & 0 & 1 & 1 & 0.10 \\
\hline Linepithema iniquum* & 135 & 14 & 1 & 150 & 1.32 \\
\hline Linepithema sp. $1^{*}$ & 66 & 0 & 0 & 66 & 0.61 \\
\hline Tapinoma melanocephalum* & 3 & 0 & 1 & 4 & 0.40 \\
\hline \multicolumn{6}{|l|}{ Ecitoninae } \\
\hline Eciton burchelli & 5 & 0 & 0 & 5 & 0.10 \\
\hline Labidus coecus & 774 & 228 & 294 & 1296 & 0.91 \\
\hline \multicolumn{6}{|l|}{ Ectatomminae } \\
\hline Ectatomma ruidum* & 0 & 8 & 42 & 50 & 3.24 \\
\hline Gnamptogenys annulata* & 1 & 0 & 0 & 1 & 0.10 \\
\hline \multicolumn{6}{|l|}{ Formicinae } \\
\hline Acropyga exsanguis* & 1 & 0 & 0 & 1 & 0.10 \\
\hline Brachymyrmex heeri* & 0 & 1 & 57 & 58 & 1.52 \\
\hline Brachymyrmex sp. 1* & 7 & 0 & 8 & 15 & 0.51 \\
\hline Brachymyrmex sp. 2* & 11 & 0 & 0 & 11 & 0.61 \\
\hline Brachymyrmex sp. 3 & 5 & 0 & 2 & 7 & 0.20 \\
\hline Brachymyrmex sp. $4^{*}$ & 0 & 0 & 1 & 1 & 0.10 \\
\hline Brachymyrmex sp. 5* & 11 & 0 & 73 & 84 & 0.91 \\
\hline Brachymyrmex sp. $6^{*}$ & 4 & 0 & 0 & 4 & 0.20 \\
\hline Camponotus claviscapus & 0 & 5 & 0 & 5 & 0.10 \\
\hline Camponotus novogranadensis* & 248 & 2 & 9 & 259 & 4.25 \\
\hline Camponotus sp. $1^{*}$ & 0 & 2 & 45 & 47 & 2.63 \\
\hline Camponotus sp. 2 & 1 & 0 & 0 & 1 & 0.10 \\
\hline Nylanderia fulva & 390 & 0 & 0 & 390 & 1.72 \\
\hline Paratrechina longicornis & 0 & 3 & 1 & 4 & 0.20 \\
\hline Paratrechina sp. $1^{*}$ & 19 & 4 & 7 & 30 & 1.42 \\
\hline Paratrechina sp. $2^{*}$ & 11 & 11 & 20 & 42 & 1.62 \\
\hline \multicolumn{6}{|l|}{ Heteroponerinae } \\
\hline Heteroponera sp. $1^{*}$ & 1 & 0 & 0 & 1 & 0.10 \\
\hline \multicolumn{6}{|l|}{ Myrmicinae } \\
\hline Acromyrmex octospinosus & 3 & 0 & 0 & 3 & 0.10 \\
\hline Apterostigma pilosum* & 1 & 0 & 0 & 1 & 0.10 \\
\hline Atta cephalotes* & 27 & 0 & 0 & 27 & 0.81 \\
\hline Cardiocondyla minutior* & 0 & 2 & 42 & 44 & 1.42 \\
\hline Cardiocondyla obscurior* & 0 & 3 & 131 & 134 & 1.92 \\
\hline Carebara brevipilosa & 31 & 0 & 0 & 31 & 0.10 \\
\hline Cephalotes minutus* & 0 & 0 & 1 & 1 & 0.10 \\
\hline Crematogaster carinata* & 6994 & 0 & 0 & 6994 & 5.26 \\
\hline Crematogaster curvispinosa* & 343 & 0 & 0 & 343 & 0.61 \\
\hline Crematogaster distans & 172 & 0 & 0 & 172 & 0.20 \\
\hline Crematogaster erecta & 0 & 0 & 57 & 57 & 0.10 \\
\hline Crematogaster evallans* & 4922 & 35 & 0 & 4957 & 2.63 \\
\hline Crematogaster limata* & 284 & 0 & 51 & 335 & 1.01 \\
\hline
\end{tabular}


Table 4: Continued.

\begin{tabular}{|c|c|c|c|c|c|}
\hline Species & Forest & Cane fields & Pastures & $\begin{array}{c}\text { Total } \\
\text { abundance }\end{array}$ & $\begin{array}{c}\% \text { occupation } \\
\text { of baits }\end{array}$ \\
\hline Crematogaster nigropilosa* & 448 & 0 & 0 & 448 & 0.71 \\
\hline Crematogaster sotobosque* & 3751 & 0 & 0 & 3751 & 3.04 \\
\hline Crematogaster sp. 1 & 178 & 0 & 0 & 178 & 0.51 \\
\hline Cyphomyrmex costatus* & 1 & 0 & 0 & 1 & 0.10 \\
\hline Cyphomyrmex rimosus* & 5 & 0 & 2 & 7 & 0.71 \\
\hline Hylomyrma reitteri & 3 & 0 & 0 & 3 & 0.10 \\
\hline Megalomyrmex sp. 1 & 4 & 0 & 0 & 4 & 0.10 \\
\hline Megalomyrmex wallacei* & 3 & 0 & 0 & 3 & 0.10 \\
\hline Monomorium florícola* & 88 & 992 & 197 & 1277 & 3.04 \\
\hline Mycocepurus smithii & 3 & 0 & 0 & 3 & 0.30 \\
\hline Myrmycocrypta sp. $1^{*}$ & 3 & 0 & 0 & 3 & 0.20 \\
\hline Myrmycocrypta sp. $2^{*}$ & 19 & 0 & 0 & 19 & 0.30 \\
\hline Octostruma balzani & 2 & 0 & 0 & 2 & 0.20 \\
\hline Octostruma sp. 1 & 4 & 0 & 0 & 4 & 0.10 \\
\hline Pheidole radoszkowskii & 0 & 0 & 27 & 27 & 0.20 \\
\hline Pheidole rugiceps* & 57 & 0 & 0 & 57 & 2.33 \\
\hline Pheidole sabella* & 79 & 534 & 4 & 617 & 2.43 \\
\hline Pheidole scalaris* & 359 & 19 & 132 & 510 & 8.20 \\
\hline Pheidole sp. 1 & 228 & 0 & 0 & 228 & 0.10 \\
\hline Pheidole sp. 2 & 0 & 325 & 80 & 405 & 0.40 \\
\hline Pheidole sp. 3 & 4 & 0 & 0 & 4 & 0.20 \\
\hline Pheidole sp. $4^{*}$ & 1124 & 0 & 7 & 1131 & 4.15 \\
\hline Pheidole sp. 5 & 4 & 0 & 0 & 4 & 0.20 \\
\hline Pheidole sp. 6 & 354 & 0 & 0 & 354 & 0.40 \\
\hline Pheidole sp. 7* & 1 & 407 & 5 & 413 & 0.91 \\
\hline Pheidole sp. 8 & 778 & 9 & 0 & 787 & 0.61 \\
\hline Pheidole sp. 9* & 52 & 0 & 0 & 52 & 0.20 \\
\hline Pheidole sp. 10 & 3 & 0 & 0 & 3 & 0.10 \\
\hline Pheidole sp. 11 & 4 & 0 & 0 & 4 & 0.30 \\
\hline Pheidole sp. 12 & 4 & 0 & 0 & 4 & 0.10 \\
\hline Pheidole sp. 13* & 0 & 0 & 3 & 3 & 0.10 \\
\hline Pheidole subarmata* & 5 & 0 & 151 & 156 & 0.91 \\
\hline Pheidole susannae* & 507 & 518 & 38 & 1063 & 7.09 \\
\hline Pheidole synarmata* & 644 & 71 & 0 & 715 & 2.43 \\
\hline Pyramica denticulata* & 22 & 0 & 1 & 23 & 0.51 \\
\hline Rogeria belti* & 1 & 0 & 0 & 1 & 0.10 \\
\hline Solenopsis geminata* & 2087 & 11653 & 15825 & 29565 & 18.02 \\
\hline Solenopsis picea & 259 & 0 & 0 & 259 & 0.30 \\
\hline Solenopsis pollux* & 1592 & 469 & 54 & 2115 & 10.53 \\
\hline Solenopsis sp. 1 & 6 & 0 & 0 & 6 & 0.10 \\
\hline Solenopsis sp. $2^{*}$ & 16 & 0 & 0 & 16 & 0.30 \\
\hline Solenopsis sp. 3 & 67 & 0 & 2 & 69 & 0.30 \\
\hline Solenopsis sp. $4^{*}$ & 37 & 0 & 5 & 42 & 1.72 \\
\hline Solenopsis sp. $5^{*}$ & 40 & 36 & 25 & 101 & 2.13 \\
\hline Strumigenys sp. 1 & 1 & 0 & 0 & 1 & 0.10 \\
\hline
\end{tabular}


TABle 4: Continued.

\begin{tabular}{|c|c|c|c|c|c|}
\hline Species & Forest & Cane fields & Pastures & $\begin{array}{c}\text { Total } \\
\text { abundance }\end{array}$ & $\begin{array}{c}\% \text { occupation } \\
\text { of baits }\end{array}$ \\
\hline Strumigenys trieces & 1 & 0 & 0 & 1 & 0.10 \\
\hline Temnothorax subditivus* & 0 & 470 & 0 & 470 & 0.30 \\
\hline Tetramorium bicarinatum & 0 & 147 & 21 & 168 & 0.51 \\
\hline Tetramorium simillimum & 0 & 1 & 4 & 5 & 0.20 \\
\hline Trachymyrmex opulentus & 1 & 0 & 0 & 1 & 0.10 \\
\hline Trachymyrmex sp. 1 & 2 & 0 & 0 & 2 & 0.20 \\
\hline Tranopelta gilva* & 0 & 0 & 138 & 138 & 0.20 \\
\hline Wasmannia auropunctata & 101864 & 22718 & 6176 & 130758 & 38.36 \\
\hline \multicolumn{6}{|l|}{ Ponerinae } \\
\hline Hypoponera sp. $1^{*}$ & 12 & 0 & 0 & 12 & 0.40 \\
\hline Hypoponera sp. 2 & 0 & 7 & 0 & 7 & 0.10 \\
\hline Pachycondyla constricta* & 25 & 0 & 0 & 25 & 0.91 \\
\hline Pachycondyla impressa* & 5 & 0 & 0 & 5 & 0.51 \\
\hline \multicolumn{6}{|l|}{ Pseudomyrmecinae } \\
\hline Pseudomyrmex boopis & 7 & 0 & 0 & 7 & 0.71 \\
\hline Pseudomyrmex sp. $1^{*}$ & 0 & 0 & 20 & 20 & 1.82 \\
\hline
\end{tabular}

${ }^{*}$ Species sharing the resource with the little fire ant (W. auropunctata).

the tropics, a large part of the anthropogenic disturbance is due to pastures for cattle raising [22], and this intensification can result in the loss of richness, especially of cryptic or specialized predator species [65]. The habitat with the lowest number of species was the cane fields, which can be related to common cultural practices in this monocrop, such as burning, application of agrochemicals, and removal of litter from the ground [66]. These factors, in contrast with management of the pastures, impact species richness more intensely by eliminating nesting and food resources.

In this study, the composition of the ant assemblage at the scale of the site and habitat could be partially structured by the abundance of $W$. auropunctata. Some studies provide evidence that the dominant species is a key factor in structuring the ant assemblages [25, 67], given that such species partially control the competitive interactions in tropical forests $[33,68]$.

Significant differences were found in ant composition among habitats. The forests are more diverse (Figure 3(c)) and have a composition separate from the other two habitats. In the study area, some mechanisms that explain the changes in species composition are related to microenvironmental variables, such as soil temperature and percent ground cover (Table 3). The loss of arboreal vegetation has a significant effect on the assemblage of ants, given that it changes microclimatic conditions, including temperature regimes and relative humidity gradients [22]. These disturbances and conversions to productive agroecosystems limit the nesting sites, generating changes in species composition [69]. For example, $W$. auropunctata is the dominant species in the forest and cane fields, whereas in the pastures $S$. geminata dominates (Figure 3(d)). The pastures have a higher temperature and little ground cover in the form of litter and pieces of bark, conditions that are adverse for the nesting of W. auropunctata. In contrast, S. geminata dominates sites where the intensification of agriculture has generated open systems with high solar radiation [70]. Although there is a clear distinction between the assemblages of ants associated with the cane fields and pastures, the differences were not significant $(P=0.063)$. One possible reason is that the cane fields in the study area are adjacent to the pastures, so there could be a movement of species between habitats. Our results agree with other studies conducted in tropical forests [24], which found that in a regeneration gradient, soil generalists ant fauna can move between adjacent areas with low complexity. Thus, they propose the existence of spatial self-correlation as an explanation, given that low-complexity habitats most likely present a more traversable surface at the scale of a foraging ant.

\section{Conclusions}

The results obtained confirm that the structure and composition of the ground ant assemblage in the tropical dry forest of southwestern Colombia differ at both site and habitat levels. These changes are related to the abundance of dominant species (primarily W. auropunctata), as well as to geographic position, microclimatic conditions, and the complexity of the habitats and sampling sites. Moreover, it is important to take into account the conditions of each site and the gradient of isolation and disturbance that there is from South to North. The sites in the South, in contrast with those from the North, are more isolated and have been submitted to greater disturbance (e.g., cattle entering the forest fragments, cutting down trees, and greater use of agrochemicals in the cane crops).

Moreover, it is hypothesized that the indirect effect of loss of species due to isolation and fragmentation can favor 
colonization by species such as $W$. auropunctata, which takes advantage of the freeing up of resources and niches due to the disappearance of other species and manages to build up a high population density. Given that agricultural conversion has favored the excessive abundance of $W$. auropunctata to the detriment of the diversity of ants associated with the dry forest, it is important to maintain the heterogeneity of the landscape. Despite the aggressive transformation of the dry forest for agriculture, these relicts conserve a large number of species whose composition depends on the site. Consequently, the loss of some of the forest fragments would theoretically mean the disappearance of some species at the local and regional scale, resulting in the homogenization of the ant fauna. Accordingly, it would be important to increase the structural connectivity between sites, which would also serve to prevent the continued degradation of the forest and improve management of the matrixes. Finally, in line with other studies [71, 72], this work reinforces the idea of how vulnerable ant assemblages are to environmental disturbance.

\section{Appendix}

For more details, see Table 4 .

\section{Acknowledgments}

Rodrigo Feitosa and Carlos Roberto Brandão, from the Museu de Zoologia da Universidade de São Paulo (MZUSP), collaborated in determining some ant species. María del Pilar López, Paloma Bejarano, Néstor Zúñiga, and Christian Bermúdez helped with the fieldwork. The Alexander von Humboldt Institute for Research on Biological Resources provided financial aid under Agreement no. 192 with the University of the Valley. The following owners and administrators of the forests gave us permission to work on their properties: Hilda Sanint (Alejandría), Carlos Ávila (El Medio), Luis Carlos Sadovnik (San Julián), and the Institute for the Research and Preservation of the Cultural and Natural Heritage of the Cauca Valley (INCIVA_El Vínculo). The evaluators' revisions were fundamental for improving the final version of this paper.

\section{References}

[1] C. Gascon, W. F. Laurance, and T. E. Lovejoy, "Forest fragmentation and biodiversity in central Amazonia," in How Landscape Changes, G. A. Bradshaw and P. A. Marquet, Eds., Ecological Studies, pp. 33-48, Springer, Berlin, Germany, 2003.

[2] W. F. Laurance and M. Goosem, "Impacts of habitat fragmentation and linear clearings on Australian rainforest biota," in Living in a Dynamic Tropical Forest Landscape, N. E. Stork and S. M. Turton, Eds., pp. 295-306, Blackwell, Oxford, UK, 2008.

[3] C. A. Peres, "Synergistic effects of subsistence hunting and habitat fragmentation on Amazonian forest vertebrates," Conservation Biology, vol. 15, no. 6, pp. 1490-1505, 2001.

[4] W. F. Laurance and H. L. Vasconcelos, "Ecological effects of habitat fragmentation in the tropics," in Agroforestry and
Biodiversity Conservation in Tropical Landscapes, G. Schroth, G. A. B. da Fonseca, C. A. Harvey, G. Gascon, H. L. Vasconcelos, and A. M. Izac, Eds., pp. 33-49, Island Press, Washington, DC, USA, 2004.

[5] D. B. Lindenmayer, R. B. Cunningham, C. F. Donnelly, H. Nix, and B. D. Lindenmayer, "Effects of forest fragmentation on bird assemblages in a novel landscape context," Ecological Monographs, vol. 72, no. 1, pp. 1-18, 2002.

[6] G. Gascon, G. A. B. da Fonseca, W. Sechrest, K. A. Billmark, and J. Sandenson, "Biodiversity conservation in deforested and fragmented tropical landscapes: an overview," in Agroforestry and Biodiversity Conservation in Tropical Landscapes, G. Schroth, G. A. B. da Fonseca, C. A. Harvey, G. Gascon, H. L. Vasconcelos, and A. M. Izac, Eds., pp. 15-32, Island Press, Washington, DC, USA, 2004.

[7] R. G. Davies, "Feeding group responses of a neotropical termite assemblage to rain forest fragmentation," Oecologia, vol. 133, no. 2, pp. 233-242, 2002.

[8] O. Barbosa and P. A. Marquet, "Effects of forest fragmentation on the beetle assemblage at the relict forest of Fray Jorge, Chile," Oecologia, vol. 132, no. 2, pp. 296-306, 2002.

[9] D. A. Driscoll and T. Weir, "Beetle responses to habitat fragmentation depend on ecological traits, habitat condition, and remnant size," Conservation Biology, vol. 19, no. 1, pp. 182-194, 2005.

[10] W. F. Laurance, T. E. Lovejoy, H. L. Vasconcelos et al., "Ecosystem decay of Amazonian forest fragments: a 22-year investigation," Conservation Biology, vol. 16, no. 3, pp. 605618, 2002.

[11] D. Janzen, "Tropical dry forests. The most endangered major tropical ecosystem," in Biodiversity, E. O. Wilson, Ed., pp. 130137, National Academy of Sciences/Smithsonian Institution, Washington, DC, USA, 1988.

[12] J. M. Hoekstra, T. M. Boucher, T. H. Ricketts, and C. Roberts, "Confronting a biome crisis: global disparities of habitat loss and protection," Ecology Letters, vol. 8, no. 1, pp. 23-29, 2005.

[13] C. A. Portillo-Quintero and G. A. Sánchez-Azofeifa, "Extent and conservation of tropical dry forests in the Americas," Biological Conservation, vol. 143, no. 1, pp. 144-155, 2010.

[14] L. Miles, A. C. Newton, R. S. DeFries et al., "A global overview of the conservation status of tropical dry forests," Journal of Biogeography, vol. 33, no. 3, pp. 491-505, 2006.

[15] A. M. Arcila-Cardona, C. Valderrama-Ardila, and P. C. de Ulloa, "Análisis de la fragmentación del bosque seco de la cuenca alta del río Cauca, Colombia," in III Congreso Internacional de Ecosistemas Secos, M. Rodríguez, G. E. Guerra, B. S. Reyes, and R. K. Banda, Eds., p. 62, Fundación Ecosistemas Secos, Bogotá, Colombia, 2008.

[16] I. Armbrecht, I. Tischer, and P. Chacón, "Nested subsets and partition patterns in ant assemblages (Hymenoptera, Formicidae) of Colombian dry forest fragments," Pan-Pacific Entomologist, vol. 77, no. 3, pp. 196-209, 2001.

[17] P. C. de Ulloa and I. Armbrecht, "Las hormigas del bosque seco tropical," in Informe sobre el Avance en el Conocimiento y la Información de la Biodiversidad 1998-2004, M. E. Chávez and M. Santamaría, Eds., pp. 345-351, Instituto de Investigación de Recursos Biológicos Alexander von Humboldt, Bogotá, Colombia, 2006.

[18] S. P. Yanoviak and M. Kaspari, "Community structure and the habitat templet: ants in the tropical forest canopy and litter," Oikos, vol. 89, no. 2, pp. 259-266, 2000.

[19] L. E. Alonso and D. Agosti, "Biodiversity studies, monitoring, and ants: an overview," in Ants: Standard Methods for Measuring and Monitoring Biodiversity, D. Agosti, J. Majer, L. Alonso, 
and T. Schultz, Eds., pp. 1-8, Smithsonian Institution Press, Washington, DC, USA, 2000.

[20] B. Hölldobler and E. O. Wilson, The Ants, Harvard University Press, Cambridge, Mass, USA, 1990.

[21] H. L. Vasconcelos, "Effects of forest disturbance on the structure of ground-foraging ant communities in central Amazonia," Biodiversity and Conservation, vol. 8, no. 3, pp. 409-420, 1999.

[22] S. M. Philpott, I. Perfecto, I. Armbrecht, and C. L. Parr, "Ant diversity and function in disturbed and changing habitats," in Ant Ecology, L. Lach, C. L. Parr, and K. L. Abbott, Eds., pp. 137-156, Oxford University Press, Oxford, UK, 2010.

[23] A. D. Gove, J. D. Majer, and V. Rico-Gray, "Ant assemblages in isolated trees are more sensitive to species loss and replacement than their woodland counterparts," Basic and Applied Ecology, vol. 10, no. 2, pp. 187-195, 2009.

[24] R. R. Silva, R. S. M. Feitosa, and F. Eberhardt, "Reduced ant diversity along a habitat regeneration gradient in the southern Brazilian Atlantic forest," Forest Ecology and Management, vol. 240, no. 1-3, pp. 61-69, 2007.

[25] X. Arnan, M. Gracia, L. Comas, and J. Retana, "Forest management conditioning ground ant community structure and composition in temperate conifer forests in the Pyrenees Mountains," Forest Ecology and Management, vol. 258, no. 2, pp. 51-59, 2009.

[26] R. R. Dunn, "Managing the tropical landscape: a comparison of the effects of logging and forest conversion to agriculture on ants, birds, and lepidoptera," Forest Ecology and Management, vol. 191, no. 1-3, pp. 215-224, 2004.

[27] K. S. Carvalho and H. L. Vasconcelos, "Forest fragmentation in central Amazonia and its effects on litter-dwelling ants," Biological Conservation, vol. 91, no. 2-3, pp. 151-157, 1999.

[28] C. A. Brühl, T. Eltz, and K. E. Linsenmair, "Size does matter-effects of tropical rainforest fragmentation on the leaf litter ant community in Sabah, Malaysia," Biodiversity and Conservation, vol. 12, no. 7, pp. 1371-1389, 2003.

[29] A. V. Suarez, D. T. Bolger, and T. J. Case, "Effects of fragmentation and invasion on native ant communities in coastal southern California," Ecology, vol. 79, no. 6, pp. 20412056, 1998.

[30] I. Armbrecht and P. C. de Ulloa, "Composición y diversidad de hormigas en bosques secos relictuales y sus alrededores, en el Valle del Cauca, Colombia," Revista Colombiana de Entomología, vol. 23, no. 1-2, pp. 45-50, 1997.

[31] I. Armbrecht and P. Ulloa-Chacón, "Rareza y diversidad de hormigas en fragmentos de bosque seco colombianos y sus matrices," Biotropica, vol. 31, no. 4, pp. 646-653, 1999.

[32] F. H. Lozano-Zambrano, P. Ulloa-Chacón, and I. Armbrecht, "Hormigas: relaciones especies-área en fragmentos de bosque seco tropical," Neotropical Entomology, vol. 38, no. 1, pp. 4454, 2009.

[33] R. Achury, P. C. de Ulloa, and A. M. Arcila, "Composición de hormigas e interacciones competitivas con Wasmanniaauropunctataen fragmentos de bosque seco tropical," Revista Colombiana de Entomología, vol. 34, no. 2, pp. 209-216, 2008.

[34] I. Armbrecht and P. Ulloa-Chacón, "The little fire ant Wasmanniaauropunctata (Roger) (Hymenoptera: Formicidae) as a diversity indicator of ants in tropical dry forest fragments of Colombia," Environmental Entomology, vol. 32, no. 3, pp. 542-547, 2003.

[35] M. Álvarez, F. Escobar, F. Gast, H. Mendoza, A. Repizzo, and H. Villareal, "Bosque seco tropical," in Informe Nacional sobre el Estado de la Biodiversidad 1997, M. E. Chávez and N. Arango, Eds., pp. 56-72, Instituto de Investigación de Recursos Biológicos Alexander von Humboldt, Bogotá, Colombia, 1998.

[36] R. M. I. Salazar, T. Gómez, G. Vargas, M. Reyes, L. E. Castillo, and W. Bolívar, Bosques Secos y Muy Secos del Departamento del Valle del Cauca-Colombia, Corporación Autónoma Regional del Valle del Cauca (CVC), Santiago de Cali, Colombia, 2002.

[37] A. Arcila-Cardona, A. M. Osorio, C. Bermúdez, and P. C. de Ulloa, "Diversidad de hormigas cazadoras asociadas a los elementos del paisaje del bosque seco," in Sistemática, Biogeografía y Conservación de las Hormigas Cazadoras de Colombia, E. Jiménez, F. Fernández, T. M. Arias, and F. H. Lozano-Zambrano, Eds., pp. 531-552, Instituto de Investigación de Recursos Biológicos Alexander von Humboldt, Bogotá, Colombia, 2007.

[38] M. M. Byrne, "Ecology of twig-dwelling ants in a wet lowland tropical forest," Biotropica, vol. 26, no. 1, pp. 61-72, 1994.

[39] B. T. Bestelmeyer, D. Agosti, L. E. Alonso et al., "Field techniques for the study of ground-dwelling ants," in Ants: Standard Methods for Measuring and Monitoring Biodiversity, D. Agosti, J. Majer, L. Alonso, and T. Schultz, Eds., pp. 122144, Smithsonian Institution Press, Washington, DC, USA, 2000.

[40] E. E. Palacio and F. Fernández, "Clave para las subfamilias y géneros," in Introducción a las Hormigas de la Región Neotropical, F. Fernández, Ed., pp. 233-260, Instituto de Investigación de Recursos Biológicos Alexander von Humboldt, Bogotá, Colombia, 2003.

[41] B. Bolton, Identification Guide to the Ant Genera of the World, Harvard University Press, Cambridge, Mass, USA, 1994.

[42] J. T. Longino, "Ants of Costa Rica," 2009, http://www. evergreen.edu/ants/AntsofCostaRica.html.

[43] N. J. Gotelli and R. K. Colwell, "Quantifying biodiversity: procedures and pitfalls in the measurement and comparison of species richness," Ecology Letters, vol. 4, no. 4, pp. 379-391, 2001.

[44] R. K. Colwell, X. M. Chang, and J. Chang, "Interpolating, extrapolating, and comparing incidence-based species accumulation curves," Ecology, vol. 85, no. 10, pp. 2717-2727, 2004.

[45] R. K. Colwell, "EstimateS: Statistical Estimation of Species Richness and Shared Species from Samples, v. 8.2," 2009, http://viceroy.eeb.uconn.edu/estimates.

[46] N. J. Gotelli and A. M. Ellison, A Primer of Ecological Statistics, Sinauer Associates, Sunderland, Mass, USA, 2004.

[47] B. McCune and J. B. Grace, Analysis of Ecological Communities, MjM Software Design, Gleneden Beach, Ore, USA, 2002.

[48] B. McCune and M. J. Mefford, PC-ORD: Multivariate Analysis of Ecological Data, v. 4, MjM Software Design, Gleneden Beach, Ore, USA, 1999.

[49] G. M. Zimmerman, H. Goetz, and P. W. Mielke Jr., "Use of an improved statistical method for group comparisons to study effects for prairie fire," Ecology, vol. 66, no. 2, pp. 606-611, 1985.

[50] J. T. Longino, "Pheidole Working Group," 2009, http://academic.evergreen.edu/projects/ants/pheidoleworkinggroup/ deployedkey/key.htm.

[51] W. M. Cook, K. T. Lane, B. L. Foster, and R. D. Holt, "Island theory, matrix effects and species richness patterns in habitat fragments," Ecology Letters, vol. 5, no. 5, pp. 619-623, 2002.

[52] A. Ballinger, P. S. Lake, and R. MacNally, "Do terrestrial invertebrates experience floodplains as landscape mosaics? Immediate and longer-term effects of flooding on ant assemblages in a floodplain forest," Oecologia, vol. 152, no. 2, pp. 227-238, 2007. 
[53] J. D. Majer and J. H. C. Delabie, "Comparison of the ant communities of annually inundated and terra firme forests at Trombetas in the Brazilian Amazon," Insectes Sociaux, vol. 41, no. 4, pp. 343-359, 1994.

[54] A. Dejean and M. Gibernau, "A rainforest ant mosaic: the edge effect (Hymenoptera: Formicidae)," Sociobiology, vol. 35, no. 3, pp. 385-402, 2000.

[55] J. H. Ness, "Forest edges and fire ants alter the seed shadow of an ant-dispersed plant," Oecologia, vol. 138, no. 3, pp. 448454,2004

[56] J. P. Lessard and C. M. Buddle, "The effects of urbanization on ant assemblages (Hymenoptera: Formicidae) associated with the Molson Nature Reserve, Quebec," Canadian Entomologist, vol. 137, no. 2, pp. 215-225, 2005.

[57] L. Tennant, "The ecology of Wasmanniaauropunctata in primary tropical rainforest in Costa Rica and Panama," in Exotic Ants: Biology Impact and Control of Introduced Species, D. F. Williams, Ed., pp. 80-90, Westview Studies in Insect Biology, Boulder, Colo, USA, 1994.

[58] L. E. Alonso, "Spatial and temporal variation in the ant occupants of a facultative ant-plant," Biotropica, vol. 30, no. 2, pp. 201-213, 1998.

[59] C. R. F. Brandão and R. R. Silva, "Synecology of Wasmanniaauropunctata, an invasive ant species (Hymenoptera: Formicidae), in continuous and fragmented areas in the Brazilian Atlantic forest," in Invasive Forest Insects, Introduced Forest Trees and Altered Ecosystems, T. D. Paine, Ed., pp. 141151, Springer, Dordrecht, The Netherlands, 2006.

[60] J. K. Wetterer and S. D. Porter, "The little fire ant, Wasmanniaauropunctata: distribution, impact, and control," Sociobiology, vol. 42, no. 3, pp. 1-41, 2003.

[61] J. Le Breton, H. Jourdan, J. Chazeau, J. Orivel, and A. Dejean, "Niche opportunity and ant invasion: the case of Wasmanniaauropunctata in a New Caledonian rain forest," Journal of Tropical Ecology, vol. 21, no. 1, pp. 93-98, 2005.

[62] I. Armbrecht and I. Perfecto, "Litter-twig dwelling ant species richness and predation potential within a forest fragment and neighboring coffee plantations of contrasting habitat quality in Mexico," Agriculture, Ecosystems and Environment, vol. 97, no. 1-3, pp. 107-115, 2003.

[63] J. D. Majer, J. H. C. Delabie, and N. L. McKenzie, "Ant litter fauna of forest, forest edges and adjacent grassland in the Atlantic rain forest region of Bahia, Brazil," Insectes Sociaux, vol. 44, no. 3, pp. 255-266, 1997.

[64] I. Perfecto, I. Armbrecht, S. M. Philpott, L. Soto-Pinto, and T. V. Dietsch, "Shaded coffee and the stability of rainforest margins in Latin America," in The Stability of Tropical Rainforest Margins: Linking Ecological, Economic and Social Constraints of Land Use and Conservation, T. Tscharntke, C. Leuschner, M. Zelle, E. Guhadja, and A. Bidin, Eds., pp. 227263, Springer, Berlin, Germany, 2007.

[65] B. T. Bestelmeyer and J. A. Wiens, "The effects of land use on the structure of ground-foraging ant communities in the Argentine Chaco," Ecological Applications, vol. 6, no. 4, pp. 1225-1240, 1996.

[66] M. Ramírez, I. Armbrecht, and M. L. Enríquez, "Importancia del manejo agrícola para la biodiversidad: caso de las hormigas en caña de azúca," Revista Colombiana de Entomología, vol. 30, no. 1, pp. 115-123, 2004.

[67] R. Savolainen and K. Vepsalainen, "A competition hierarchy among boreal ants: impact on resource partitioning and community structure," Oikos, vol. 51, no. 2, pp. 135-155, 1988.
[68] M. Kaspari, "Litter ant patchiness at the 1- $\mathrm{m}^{2}$ scale: disturbance dynamics in three neotropical forests," Oecologia, vol. 107, no. 2, pp. 265-273, 1996.

[69] I. Armbrecht, I. Perfecto, and J. Vandermeer, "Enigmatic biodiversity correlations: ant diversity responds to diverse resources," Science, vol. 304, no. 5668, pp. 284-286, 2004.

[70] D. Nestel and F. Dickschen, "The foraging kinetics of ground ant communities in different mexican coffee agroecosystems," Oecologia, vol. 84, no. 1, pp. 58-63, 1990.

[71] L. E. Alonso, "Ants as indicators of diversity," in Ants: Standard Methods for Measuring and Monitoring Biodiversity, D. Agosti, J. Majer, L. Alonso, and T. Schultz, Eds., pp. 80-88, Smithsonian Institution Press, Washington, DC, USA, 2000.

[72] A. N. Andersen and J. D. Majer, "Ants show the way down under: invertebrates as bioindicators in land management," Frontiers in Ecology and the Environment, vol. 2, no. 6, pp. 291298,2004 

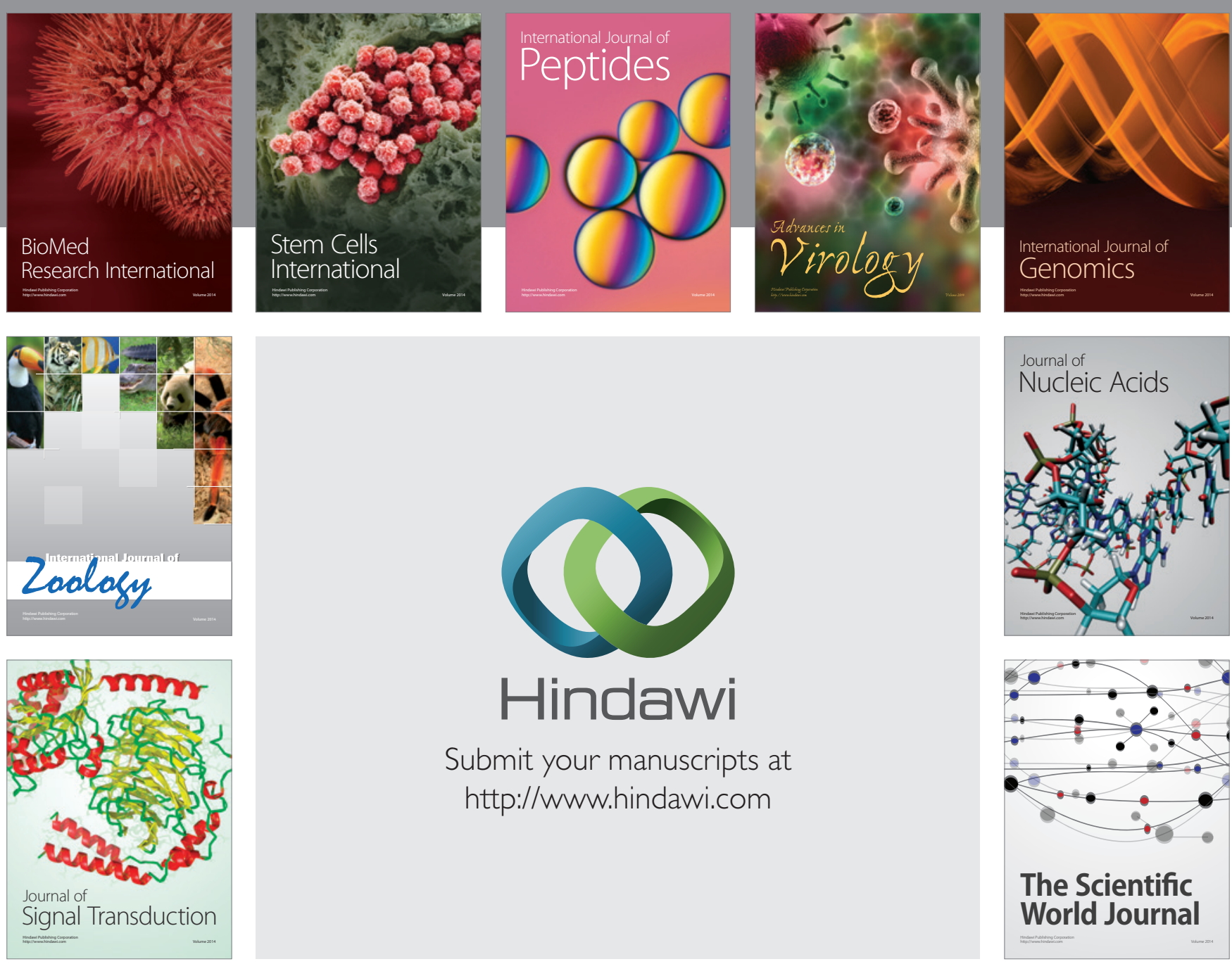

Submit your manuscripts at

http://www.hindawi.com
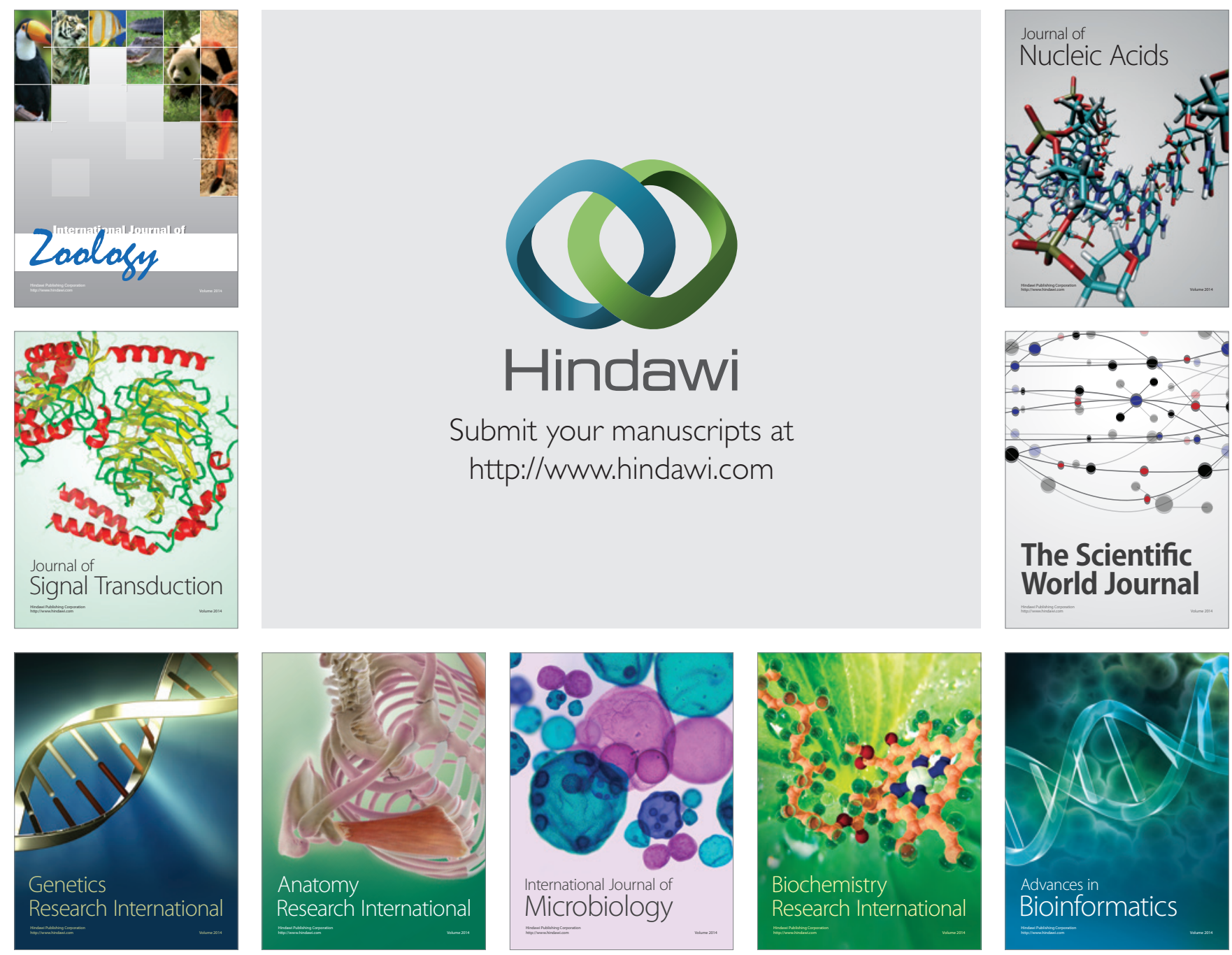

The Scientific World Journal
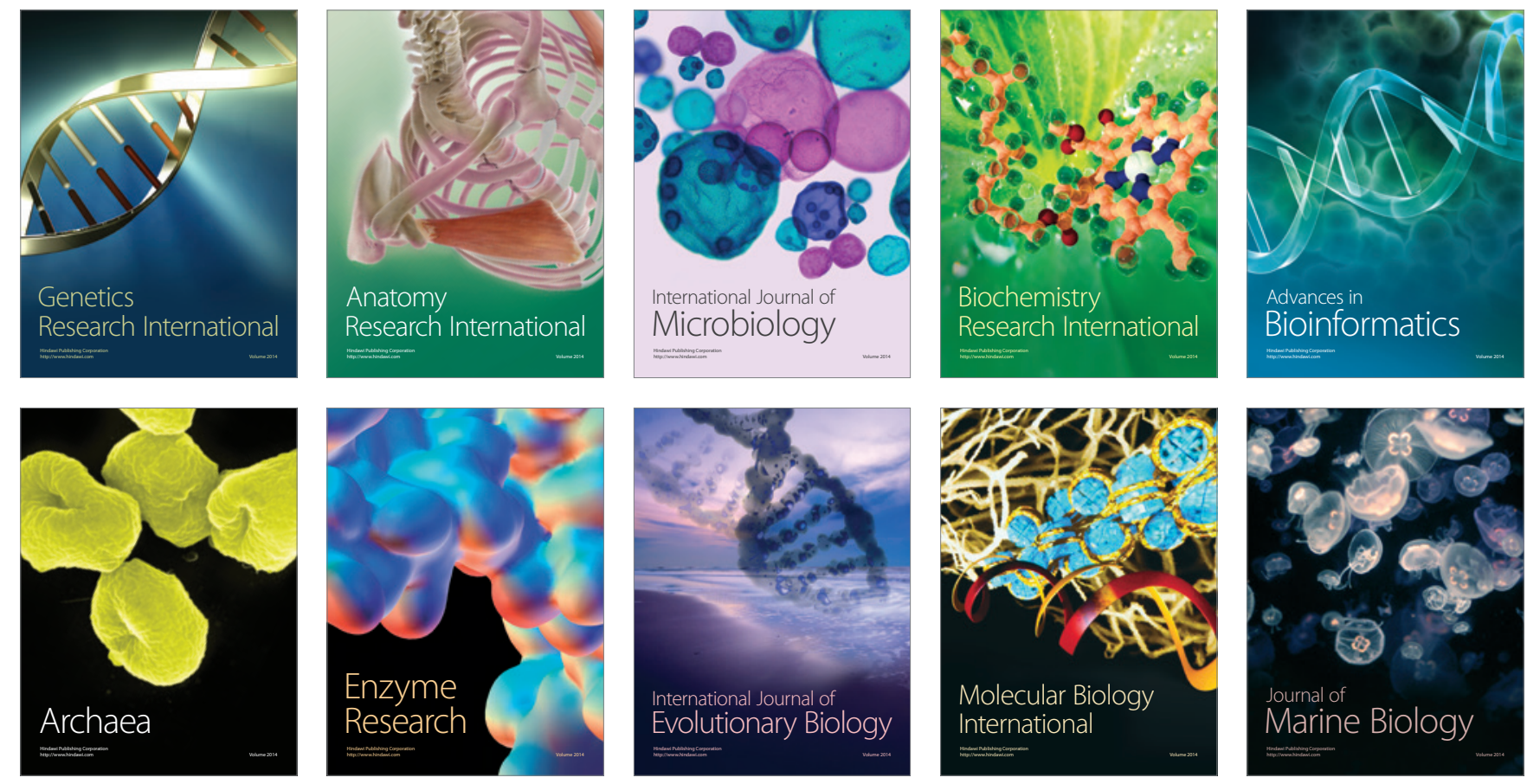